\title{
The Fading Phase of Igbo Language and Culture: Path to its Revitalisation
}

\author{
George E. Onwudiwe \\ Http://dx.doi.org//10.4314/ujah.v17i 2.7
}

\begin{abstract}
In recent times, some concerned linguists, lovers of the Igbo language and indeed, owners of the language have been asking questions about possible strategies to be adopted in resuscitating the Igbo language and culture which critics and observers have warned are depreciating in value and usage. The Igbo of South East Nigeria, as well as various governments in the Igbo region have in their own various ways jumped into action to revive and save the situation through the organisation of cultural activities and forums for the promotion of Igbo language and culture and legislations. Commendable as these attempts may be, the issue which does not yet appear properly addressed is the need to identify the factors responsible for the present state of Igbo language and culture and the possibilities of workable strategies to remedy the situation. This paper therefore, is an attempt to interrogate the receding utilization of Igbo language and culture using UNESCO's 2002 and 2003 nine-point criteria of the Ad Hoc Expert Group on Endangered Languages as bases for our study and recommendations. The study has attempted to get at the root of what the author considers the crux of the matter through the study of the philosophy of the Igbo man towards himself, his environment and his personal effects, and has discovered that the bane of Igbo language and culture is the Igbo man's attitude towards that which is his, and his easy enchantment with foreign cultures. The paper then recommends a total reorientation of the Igbo man's core philosophy as a panacea to the problem, among others. The revelations of this paper will benefit linguists, the Igbo, and indeed scholars.
\end{abstract}




\section{Introduction}

The question of the state and fate of Igbo language and culture has for a long time now been of great concern to many linguists and lovers of the Igbo race and her language especially when one recalls the warnings of UNESCO and other world bodies and linguists who foresaw the impending danger. The concern being expressed by researchers, scholars and concerned individuals, is probably hinged on the fact that language and culture form the identity mark for man. In other words, man coexists with people with diverse languages and cultures. One thing that identifies and classifies one group from another is her language and culture. Hence, culture has been said to reflect "the sum total of human creation, everything that is a product of human mind" (Ebisi, 2015:31). Culture will include all the systems, techniques and tools which make up man's way of life. This is classified into material and nonmaterial culture. Whereas the material culture consists of observable aspects of man's way of life such as their type of houses, clothes, tools, implements, etc, the nonmaterial aspects are presented in his custom, belief, values, and means of regulating interaction with other humans and with the supernatural. Also in this category of man's culture is his language which is considered a key component of culture. It is the primary medium for transmitting much of man's culture. As a result language learning in children is a process of enculturation. In the words of Adekunle (1990), language is a tool for communication. He further sees communication as a process of interaction between two or more individuals. From the foregoing, it can be contended that there is a correlation between the form and content of language and beliefs, values and needs present in the culture of its speakers.

All together, a people's culture presents a collection of their ideas and habits. Their cultural background is 
intertwined with the bases of their existence so much so that it moderates how members of the society think and feel, as well as directs their actions and defines their outlook. These elements of culture are embedded in language and are expressed in the systems of usages and procedure, of authority and mutual aid, of groupings and divisions, of controls of human behaviour and of liberties peculiar to that society. It goes to suggest therefore that the language and culture of a people depict their attitude to life.These assertions tend to pose some questions about the authenticity of the existence of any society that neglects her language and culture, perhaps in favour of foreign language (and culture). They also throw question on the consciousness of any society that opts to live on borrowed garment, nay reduce her members to living ghosts. The assertions most importantly serve as eye openers to any society, like the Igbo society which seems to have flagrantly dumped her language and culture. It is then hoped that the expositions to be made by this paper will help to reorient such societies as the Igbo to review their philosophy about their language and culture and return to their real identity.

\section{Issues on Language Endangerment and Language Extinction}

Language serves as both custodian and vehicle for cultural mobilisation. This endows on language a very significant place in the essence of man. Any danger that touches language therefore touches man, his thinking and indeed his being and essence. No wonder numerous literatures abound on language endangerment and language extinction. Fromkin, Rodman and Hyams (2003:524) support the position of language in the scheme of man's existence and habits with the following pronouncements by two notable linguists. First, Michael Krauss says: "Any language is supreme achievement of a uniquely human collective genius, as divine and 
unfathomable a mystery as a living organism"; and Samuel Johnson regrets: "I am always sorry when any language is lost, because languages are the pedigree of nations". These statements justify the importance of language in human existence, as well as give credence to any call for preservation and sustenance of any language.

Contributing on the causes of language endangerment, Usman (2014) cites the following UNESCO's pronouncement on the subject:

A language is endangered when its speakers cease to use it, use it in fewer and fewer domains, use fewer of its re-gisters and speaking styles, and/or stop passing it on to the next generation (52).

Again, citing Krauss (1992), Usman (2014:54) presents Krauss's tripartite classification of levels of language endangerment as follows:

"(1) Moribund languages" - Native languages that are no longer transmitted to children by adults.

"(2) Endangered languages" - These are languages that still enjoy the competence of adult speakers and are still being transmitted to children on intergenerational basis. These languages, he says, stand the risk of sliding into the category of moribund languages by the end of the twenty-first century if nothing is done to promote and protect them.

"(3) Safe languages" - These are very robust languages that still enjoy active usage by the community of their speakers. They are actively used in intergenerational communication and may still be used in the next 100 years or more.

Usman further gives UNESCO's classification of endangered languages. In this classification, five strata categorisation by the Organisation are given as follows: "safe", "vulnerable" (languages not spoken by children outside the home), "definitely endangered" (languages not 
spoken at all by children), "severely endangered" (languages spoken by only the oldest generations) and "critically endangered" (languages spoken by only few members of the oldest generations). Fromkin, Rodman and Hyams also enlist the different fate that can befall any language to include "Sudden death" - when and if all the speakers of the language die or are killed; "Radical language death" - similar to sudden death in its abruptness, but specifically, rather than speakers dying, they all stop speaking the language, often because of political repression or genocide. Then, to avoid being identified as "natives", speakers simply stop speaking their native language, and children are unable to learn a language not spoken in their environment. The language dies when the last speaker dies. Other types of fate that can befall a language are: "Gradual language death" - This is considered most common way for a language to go extinct. According to them, it happens to minority languages that come in contact with a dominant language, and finally "Bottom-to-top language death" - This is used to describe a language that survives only in specific contexts, such as liturgical language. These classifications are rubrics provided to help in appraising the state of people's languages and therefore serve as checks to prevent further endangerment or death or extinction.

Fromkin, Rodman and Hyams (2003:525), also concerned about this malady note inter alia:

Linguists have placed many languages on an endangered list.

They attempt to preserve these languages by studying and do-cumenting their grammars - the phonetics, phonology, and so on - and by recording for posterity the speech of the last few speakers.

This is a messy state. No wonder Samuel Johnson's cry above. So, any language that the native speakers do not hold 
tenaciously can suffer any one of the categorised levels of endangerment above, and it may get to the worst level when the language gets totally extinct.

\section{Rubrics for Assessing Language Vitality}

In order to check the vitality or endangerment of any language, certain measures need be taken. Prominent among them is that the native speakers must first be conscious of the state of their language. They also need to compare the usefulness of their language with that of other known world languages.

To achieve this, UNESCO in 2002 and 2003 set up an 'Ad Hoc Expert Group on Endangered Languages' to develop a methodology for assessing the vitality of a community's language. According to Usman, (2014:55), the Committee identified six factors for evaluating the vitality and state of endangerment, two factors to assess language attitudes and one factor to evaluate the urgency of the need for documentation, totalling nine factors. The Committee's report thus produced the following criteria:

- Intergenerational language transmission.

- Absolute number of speakers.

- Proportion of speakers within the total population.

- Shifts in domains of language use.

- Response to new domains and media.

- Availability of materials for language education and literacy.

- Government and institutional language attitudes and policies including official status and use.

- Community members' attitude towards their own language.

- Amount and quality of documentation. 
The above criteria will serve as checks for any ailing language and help any conscious community to rescue her language from endangerment and extinction.

\section{Glooms in the theatre of Igbo language and culture}

The Igbo language and culture has for some time now been undergoing a depleting phase in quality and essence. The depletion gingered so many concerned and patriotic Igbo linguists and speakers into action. For instance, Ejiọfọ (2013) contended that one aspect of Igbo culture that needs to be secured and promoted to an enviable stand in Nigeria is the language. Earlier Ejiofor (2006) had exclaimed that it is very surprising that the Igbo people appear to sit complacent and carefree while their language fades away gradually; while Ejiofọ (2013) accuses the Igbo people as the cause of nosediving of the quality and usage of Igbo language and culture.

So many things can be said about the glooms in the theatre of Igbo language and culture. But only few striking and dangerous ones can be mentioned here. The Igbo people now slowly but steadily strip themselves off their culture through their reckless and indifferent attitude towards their language and culture thus, letting go their identity.

Oguejiofor (2004:4-5) records a good number of these unconcerned attitudes of the Igbo people towards their language. They include as he laments: "To some Ndi Igbo, it is a mark of elitism to deny their children the wisdom, philosophy and thought encapsulated in Igbo language by shielding them off their mother tongue". This carefree attitude of this segment of the Igbo people is about the commonest but most gruesome of the dangers facing the Igbo language and culture today in fact; it has even smeared into almost the rank and file of the race, including most pitiably the illiterate ones. The Igbo man has been known for clamouring and in fact being enchanted by foreign things, particularly other people's languages. It is no longer news that today we prefer to speak 
English language instead of Igbo, even in Churches where over ninety percent of the worshippers are of Igbo origin and speak and understand Igbo language better. This cannot obtain in western and most African countries where the best they can do for you is engage an interpreter while they talk in their own native language. The worst offenders in this crime are the Traditional Rulers who, by their calling and position should be the custodians of their culture. Oguejiofor further states inter alia: "Today it is a pride for some parents to deceive their children to believing that every male adult is an uncle and any other woman qualifies for an aunt. Absurd". This is stupendous ignoramus; yet they pride over the nauseating attitude in the guise that they are modern and enlightened.

Other carefree attitudes as noted by Oguejiofor (2004) include: "It is now a fashion for Ndi Igbo to wear all sorts of look by asking 'Ndi Igbo onwere dress?'”. Again, he accuses the elite and the well-to-dos in the society as the main culprits here, and further concludes that this explains why a young Igbo man celebrates his traditional marriage in traditional Yoruba or Hausa costume; while some Ozo titled men do throw away their revered red cap in place of some lesser caps from other ethnic groups. This is really pitiable. He finally recapitulates the Igbo man's philosophy that identifies and sets him apart from other people which are thoughtlessly allowed to fade away in the following lamentation:

We have lost sincerity and are no longer dependable and reliable because we have lost our value system. Conseque-ntly, the forces of desirable Igbo cultural norms and values that propelled the then Ndi Igbo to greater heights are tod-ay no longer at work. We have by omission or commission, abandoned our culture which gives life 
authentic bearing. We have played down our language which refines man (6).

\section{Path towards Actual Revitalisation of Igbo Language and Culture}

The summary (above) of the unpatriotic attitude is, in fact, the main instigating force which aroused many reactions, lectures, organisations, and so on by individuals, governments and institutions to save the image of the Igbo man through rescuing his language and culture. Onwudiwe (2012) in his own reaction says that the wind of change is heavily blowing to erode both the Igbo man and his language and culture away. The attitude, he observes has also turned the Igbo man away from who he had been to doing such unbecoming things as laziness, armed robbery, street begging, murder, kidnapping, pettiness and the likes. They are unfortunately easily gullible. These attitudes were totally alien in the life and culture of the Igbo man. They have presently reduced the Igbo man to 'nobody' in the Nigerian polity. Now, the Igbo man more or less depends on the 'scraps that fall down from the master's table'. No wonder the nowadays Igbo man is easily swayed with little pittance.

In like manner, the Nnamdi Azikiwe University, Awka, through her annual (now biennial) Chief Dr. F. C. Ogbalu Memorial Lecture series has been very critical in choosing topics for the Lecture. For instance, the following lecture topics:

"Ọọ̣dụ Asụsụ Igbo: Oge Ugbu a na Ọdịniihu (2011);

"Nhafe Asụsụ Na Omenala: Olileanya Ndị Igbo" (2012);

"Nke m Akọlam: Ndị Igbo na Asusu Ha" (2013);

"Agbammbọ Ndị Igbo na Nkwalite Asụsụ na Omenala Ha" (2015); to mention but a few are all efforts towards reorienting the mind of the Igbo man. Notable too is the yeoman's efforts of Professor Pita Ejiọfọ and his 'Otu Sụwakwa Igbo'; his writings, talks and lectures on reviving the language are part 
of the movement. Same goes for the legislations by the State Houses of Assembly in the South Eastern part of the country (championed by the Anambra State government), and various pronouncements by state governments in the region to dress in Igbo cultural attire to work on certain days of the week; and to use Igbo language as official language of communication in the offices.

All these are laudable and commendable. But the questions remain: how far are these implemented? How many people keep to these directives? How can it be explained that we use our native language on our native land and dress in our native dresses (whatever people understand them to be) only on selected days? To a very great extent such attitude is as hypocritical as it is political. The question still remains: how do we touch the inner man and stir him to consciousness to see reason in Samuel Johnson's earlier regret, and UNESCO's and other well meaning individuals' and organisations' relentless efforts and warnings aimed at rescuing people's language and culture such as this: "...the disappearance of any one language constitutes an irretrievable loss to mankind ..." (Fromkin, Rodman \& Hyams: 2003:526).

To chart a course for a more permanent solution to the danger therefore, we must first channel our mind towards reorienting the Igbo man's view and understanding of language and culture. Oguejiofor (2004:8) aligns himself to this declaration by his quotation of Igwe Osita Agwuna's call for "a drastic reorientation of the disdainful attitude of Igbo elites towards their traditional values". This is the main recommendation of this text for, if the Igbo man fails to return to sanity and consciousness about his eroding being and essence, then any effort by anybody, government or institution may remain effort in futility. And, the UNESCO's Ad Hoc Expert Group on Endangered Languages criteria on 
"Community members' attitude towards their own language" touches on this recommendation.

According to Nnabuchi (1987: ix),

Everything has been done to erase our belief system from the face of the earth but whether this is right thing to do this time when every group is desirous of making its heritage available to the world as its contribution to the development of religion, philosophy, occultism, science and general understanding of the environment in which we dwell is a matter for posterity to pass judgement on the Igbos.

Subtle though Nnabuchi's submission may appear, it is a serious call for the Igbo man to re-examine his sensibility and return to full consciousness and match on with the rest of the world's human races. The import of this statement is anchored on the UNESCO Ad Hoc Expert Group's criteria which demand that any living language (and culture) should have the quality of "Response to new domains and media", and "Availability of materials for language education and literacy". Succinctly put, it is here being recommended that the Igbo man should practise his culture and be proud and courageous to make available and share his rich culture and philosophy.

In the words of Maduka (1978:22), "Our people are heading to cease to be the people they once were and never to become any definite thing". This statement borders on the much talked about language and culture as identity mark. Therefore, it is strongly being recommended that for the Igbo race to remain in existence and remain relevant, members of the race must not only practice their culture, but more importantly pass it on to the upcoming generation. This is the demand of the following UNESCO's criteria: 
"Intergenerational language transmission", "Absolute number of speakers" and "Proportion of speakers within the total population".

As Anigbo (1992:68) laments: "If it is true that the language of the people is the expression of its soul, then the administration must bear the responsibility for the terrible homicide which the displacement of vernacular education implies". This is a restatement of our earlier observation that the sincerity of the governments and legislators on the use of Igbo language and speaking Igbo in the offices on select days are seriously in doubt, and the UNESCO's criteria on "Government and institutional language attitudes and policies including official status and use" anchors here. Therefore, we here recommend that governments in the Igbo states should not only make the teaching and learning of Igbo language and culture compulsory across all their primary and secondary schools, but more importantly make Igbo language one of the qualifying subjects for admission into their institutions of learning. They should also ensure strict implementation of the National Policy on Education recommendation on the use of local language in teaching at the pre-primary and the junior primary levels. Besides, they should remove the restriction of the use of Igbo language and dressing in Igbo attire on select days for, it is a shame to regulate somebody on when to use his native language and attire in his home land. They should also supervise and ensure strict compliance of the earlier promulgated laws particularly those on the use and practice of Igbo language and culture.

The attitude of the Igbo in regarding Igbo language as deficient in vocabularies, that is that Igbo language is incomplete is a very dangerous one that needs to be dropped entirely. Modern language studies clearly state that all languages are created equal. Let us note these statements by Blake (2008:6-7) concerning the statements made by his 
fellow course mates on the reaction of people if they were to study one of the native languages of Australia:

These views reflect a widespread notion that some languages are 'primitive', in particular the languages of the people living a traditional lifestyle. While it is true that such people have not been caught up in the growth of civilization and have not acquired a host of inventions ranging from telephones to television, it is not true that their languages are less sophisticated ... All these languages have a set of speech sounds and they all have rules for making up words, and rules for putting words together in phrases and sentences. All these languages have words for whatever they want to talk about in their experience.

The exposition above, simply put, is telling us that every language is equal with others and relevant to the owners insofar as it aids communication and interaction in that community. It is also educating people that no language, no culture will have a name for any concept or idea that is foreign to it. However, it reveals that in any situation of cultural contact or enculturation, the language has the potential to create words and expressions for such new concepts. Therefore, "Community members' attitude towards their own language", and "Shifts in domains of language use" as provided by the Ad Hoc Expert Group refer to this. Once the Igbo people get this all-important education about their language and culture and thereby disabuse their mind of this erroneous belief, the better for them and their language.

Finally, the criterion on "Amount and quality of documentation" simply challenges the Igbo elites and scholars to write and publish in Igbo language. A situation where we 
read in another language (English, French, German, etc.) and translate or transliterate into Igbo does not augur well for the growth and development of the Igbo language. Almost all the literatures used by Igbo language teachers are written in foreign languages. This is not helping in the growth of the orthography and does not help in creating metalanguage in different fields of Igbo studies. Strongly being recommended here, is development of Igbo language for the study of medicine and other sciences, including computer science and Linguistics, as hinted by Blake (2008). This will help carry both the then and the modern Igbo man along in the whole campaign, and also project the Igbo language to the outside world and more importantly enhance intergenerational language transmission.

\section{Summary and Conclusion}

Efforts at revitalizing and sustaining any ailing language is often a serious one for the people who understand the effect endangered language has on the existence of the owners. In fact, an endangered language is like a very sick person who is remanded in intensive care unit. This will enable us understand why linguists, well meaning individuals, governments, institutions, world organisations, etc. raise alarm, organise workshops, give talks, lectures and spend huge sums of money and time in the bid to save the situation. One notable world organisation in this mission is the UNESCO; hence, they raise alarm in the event of any language that is threatened. Sometimes, these warnings are well received and timely adjustments are made. But, some people turn deaf ears over such warnings, thereby letting the danger grow into debilitating stage for their language.

In any case, what is recommended here is to be conscious and always adjust in line with the changing time. To succeed, therefore requires holding on to the good aspects of the people's philosophy about life and to be pragmatic in 
their attitude and use and practice of their language and culture. In the case of Igbo language and culture, commendable campaigns and efforts have raged on, but more pragmatic and radical steps are actually required if meaningful impacts must be made in the effort. Therefore, policies should be transformed into action, while the Igbo man must change his attitude towards his language and culture, nay himself in line with UNESCO's Ad Hoc Expert Group on Endangered Languages' nine-point criteria. This will enable the Igbo man and his language to join in the globalisation trend; otherwise, he will watch himself go down the drain of "never to become any definite thing".

\section{George E. Onwudiwe}

Department of Igbo, African and Asian Studies Nnamdi Azikiwe University, Awka, Nigeria

\section{References}

Adekunle, M. A. (1990). "Language in a Multicultural Context" in E. Nolue Emenanjo (Ed.) Multilingualism, Minority Languages and Language Policy in Nigeria. Agbor: Central Books.

Anigbo, O. A. C. (1992). Igbo Elite and Western Education. Onitsha: Africana Fep Publishers.

Anizoba, Obed M. (2013). "Nke m Akọla m: Ndị Igbo na Asụsụ Ha". $8^{\text {th }}$ Chief Dr. F. C.

Ogbalu Memoral Lecture. Onitsha: Varsity Publishing Company.

Blake, B. J. (2008). All About Language. Oxford: oxford University Press.

Ebisi, T. E. (2015). "Culture and Cultural Expressions in Nigeria" in Ikenna Alumona \& Cynado Ezeogidi (Eds.) Nigerian Peoples and Culture: A Reader. Enugu: Ryce 
Korex Publishers.

Ejiọfọ, Pita (2013). Obibi Ndu Ndị Igbo: Akwukwo Abu. Awka: Valid Publishing Company.

Ejiofor, Pita (2006). Íbekù Ndị İgbò Màkà Ásụsụu İgbò. Enugu: Nolix Educational Publications.

Fromkin, V., Rodman, R. \& Hyams, N. (2003). An Introduction to Language. Wadsworth: Thomson.

Maduka, M. (1978). "Christians and Ọzọ title taking in Igbo land" in Ugo Vol. 1, No 2.

Nnabuch, N. (1987). In Defence of Igbo Belief System. Enugu: Life Path Printing Press.

Nwaozuzu, G. I. (2015). “Agbammbọ Ndị Igbo na Nkwalite Asụsu na Omenala Ha". $9^{\text {th }}$ Chief Dr. F. C. Ogbalu Memorial Lecture. Onitsha: Varsity Publishing Company.

Oguejiofor, Umeadi C. (2004). "Ndi Igbo and Their Language and Culture: How Far, So Far". Paper presented at the Seminar Organised by Department of African Languages of Nnamdi Azikiwe University, Awka.

Ohiri-Aniche, C. (2011). "Ọnọdụ Asụsụ Igbo: Oge Ugbu a na Odịniihu”. $6^{\text {th }}$ Chief Dr. F. C. Ogbalu Memorial Lecture. Onitsha: Varsity Publishing Company.

Onwudiwe, G. E. (2012). “Anya Ruo Ụlọ: Akpọmoku Nwaamaala Igbo Ọbụla aghaghị ịza”. Akwụkwọ Ngụpụta na Mmemme Nnata na Mmechi Afọ Anambara n'Ama Egwuriegwu Ekwueme, Awka.

Usman, Bukar (2014). Language Endangerment and Cultural Diversity in Biu Emirate. Abuja: Klamidas Communications.

Ụzọchukwu, Sam (2012). 'Nhafe Asụsụna Omenala: Olileanya Ndi Igbo". $7^{\text {th }}$ Chief Dr. F. C. Ogbalu Memorial Lecture. Onitsha: Varsity Publishing Company. 